\title{
An Implementation of Lean-ergonomic Approach to Reduce Ergonomic Parameter Waste in the Manufacture of Crackers
}

\author{
Guntarti Tatik Mulyati, Suharno, and M.A. Muharom \\ Department of Agroindustrial Technology, Faculty of Agricultural Technology \\ Universitas Gadjah Mada, Jl. Flora No.1 Bulaksumur 55281, Indonesia. \\ Email: guntarti.ftp@ugm.ac.id
}

\begin{abstract}
"Subur crackers company" in Yogyakarta, Indonesia, is a manufacturer of crackers that operate conventionally. Various manual processes were employed to produce chips using several tools. The research objectives was to identify the ergonomic waste in the production process of crackers making. Ergo waste in the company was assessed based on working posture using Ovako Working Assessment System (OWAS) methods. The research indicated that the entire workstation have ergo waste. It was difficult to reduce ergo waste due to fixed design of most equipment and workplace environment. The process of cooking, kneading, molding dough, steaming and drying required more attentions on implementation of lean-ergonomic approach.
\end{abstract}

Keywords: Crackers, Lean-ergonomics, Ergo waste.

\section{INTRODUCTION}

Crackers or "Kerupuk" in Indonesian language is a fried-based complementary food product which was made from a mixture of wheat flour and tapioca flour. Crackers is a very popular snack in Indonesia and is widely used as a complement when eating rice. Cracker production process consists of manufacturing of seasonings, mixing materials and kneading, thinning, molding, steaming, and drying. Some processes were pursued semi-automatic by worker while making the seasoning and drying is done manually.

The primary goal of lean approach is to increase profit by reducing cost and increasing productivity. This could be achieved by the elimination of waste in the production. Lost work associated with Work-related Musculoskeletal Disorders (WMSDs) can be significant waste. Implementation of lean production can help to eliminate WMSDs causal factors, such as work layout improvement. WMSDs is related to mechanical and physiological process, work intensity and duration, multiple work and personal causes (Woolley \& Armstrong, 2012). The combination of lean thinking and ergonomics results in a system where the worker is as efficient, safe and comfortable as possible while trying to produce the best product possible (Walder et al., 2007).

Reducing ergo waste is highly important for cracker industry. Some research were pursued in cracker industry. Subur crackers industries is one sample of many similar industries in Yogyakarta. Handayani et al (2006) found the existence of a waste of time, overproduction in the process of making crackers "Subur" and have managed to eliminate it in various ways. Whereas Rahayu et al (2013) identifies health and safety work on the process of making crackers and found that there is a danger of ergonomic in some production processes. However none of the research were related to reducing ergo waste.

This paper is a case study explaining about implementation of lean ergonomics in the production system at "Subur" crackers plant in Yogyakarta, Indonesia. In this scope, the research objectives was to identify the ergonomic waste in the production process of crackers making. 


\section{MATERIAL AND METHODS}

The case study of research were pursued at industry crackers "SUBUR", Yogyakarta, Indonesia during period of August 2015. The product is a dried crackers that are large with a diameter of $10 \mathrm{~cm}$ and the small one with 5 $\mathrm{cm}$ in diameter. Dried crackers is fried by the purchaser on the frying pan facilities prepared by the manufacturer and then deposited to the retailer or food stalls.

The parameter of ergo waste in Crackers plant is more than one parameter because it contained more than one kind of ergo waste in the production process, those are process, excessive motion, and transportation.

Waste of process is reviewed using the Operation Process Chart (OPC). Information within the OPC regarding the purpose of doing a stage of the process, the processing time, the end result of the process, used to decide a process it is necessary or could be replaced by other processes.

The presence of excessive movements analyzed by assessing working postures using the OWAS method (Ovako Working Assessment System). Work posture stands, lunges, squats, can be analyzed with the same method. The excessive movement was caused by bringing the load when handling the material analyzed in the Power Zone area.

Waste of transportation becomes important because all the material handling is manually. From to chart is a chart that describe the displacement of a number of goods which move from one place to another. From-to chart can help identify transportation waste easily.

\section{RESULT AND DISCUSSION}

Handayani et al (2014), Rahayu et al (2014) and Muharom (2015) found that there were seven waste in crackers industry. Ergo waste demonstrated by the existence of process waste, motion waste and transportation waste.

In Figure 1, there are 7 operation process to produce crackers that starts from cooking the seasoning until the drying using the dryer. The output of seasoning process $(\mathrm{O}-$ 1 means operation process 1 : cooking the seasoning) is a liquid seasoning as a raw material for the manufacture of crackers (O-2 until O-7). In $2^{\text {nd }}$ operation, seasoning liquid mixed with tapioca flour and kneading into the dough. After being formed into a thin sheet on the thinning process $(\mathrm{O}-3)$, the batter is mold $(\mathrm{O}-4)$ and steamed $(\mathrm{O}-5)$. The last process is drying, Operation 6 and 7.

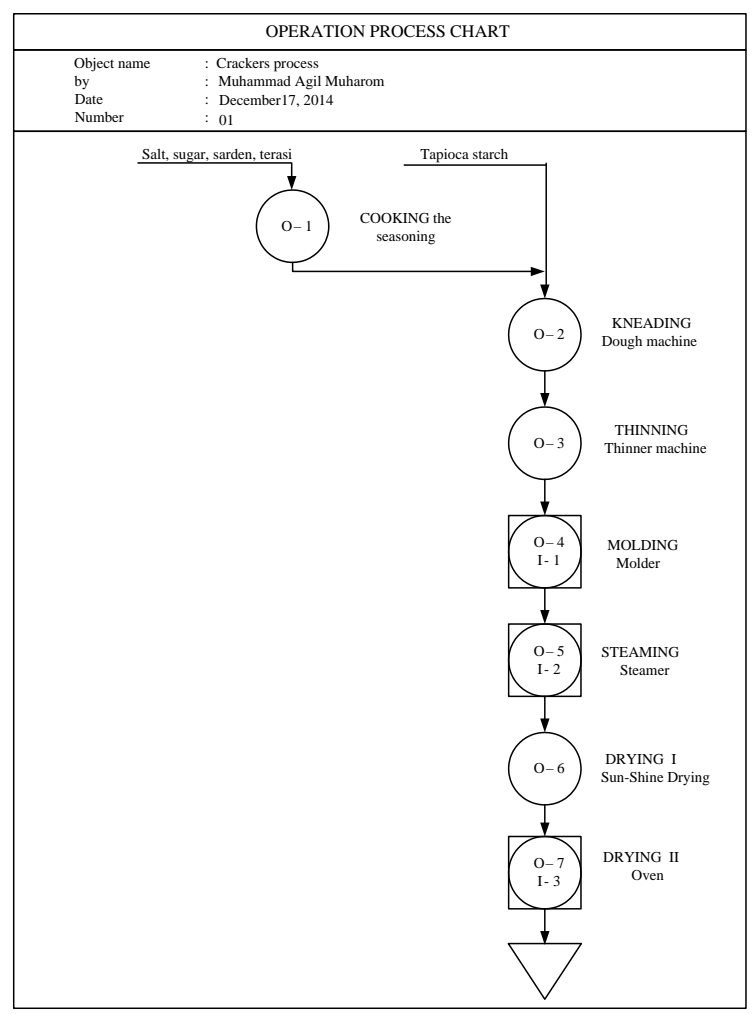

Figure 1. Operation Process Chart Cracker

The similar objectives of Drying I and II are lowering the levels of water crackers. Operation 6 (first drying: O-6) was the drying using sun-shine. Results of drying, the crackers stored in the open backs. If want to fry crackers, we must dried in a dryer machine first (second drying : O-7). This causes the occurrence of over production (Handayani et al, 1995). The industry could implement just in time production schedule to fry the product after first drying with sun-shine. There is no need drying with dryer in next day. Therefore, the Operation 7 can be eliminated.

The waste of unnecessary motion is particularly related to ergonomics. Excessive motion consist of bending, twisting, lifting, reaching, and walking. These should be dealt with as soon as they are recognizes (Walder et al., 2007).On the production process of making crackers manually, the fifth excess motion is in a workers posture. So the final score OWAS is obtained be high. The OWAS posture score indicated worth 1 means 
working postures are safe. the worth 4 means working postures are at risk of incurring a MSDs and working methods should be improved at that time

The three risk factors for potential development of work-related MSDs are high force, awkward posture and excessive repetition. That physical risk factors can be reduced or eliminated altogether by adhering to proper workplace design principles and appropriate us of assist devices (Walder et al., 2007). The results of the assessment of workers were indicated in table 1.

Table 1. The waste of excessive motion

\begin{tabular}{|l|c|l|}
\hline OPERATION & $\begin{array}{l}\text { OWAS } \\
\text { score* }\end{array}$ & \multicolumn{1}{|c|}{ REASON } \\
\hline $\begin{array}{l}\text { Cooking } \\
\text { seasoning }\end{array}$ & $1-4$ & awkward posture \\
\hline Kneading & $1-4$ & $\begin{array}{l}\text { high force, } \\
\text { awkward posture }\end{array}$ \\
\hline Thinning & $1-4$ & $\begin{array}{l}\text { high force, } \\
\text { awkward posture }\end{array}$ \\
\hline Molding & $1-4$ & $\begin{array}{l}\text { excessive } \\
\text { repetition, high } \\
\text { force, } \\
\text { awkward posture }\end{array}$ \\
\hline Steaming & $2-4$ & $\begin{array}{l}\text { excessive } \\
\text { repetition, high } \\
\text { force, } \\
\text { awkward posture }\end{array}$ \\
\hline Drying I & $1-4$ & $\begin{array}{l}\text { excessive } \\
\text { repetition, } \\
\text { awkward posture }\end{array}$ \\
\hline Drying II & $1-4$ & $\begin{array}{l}\text { excessive } \\
\text { repetition, } \\
\text { awkward posture }\end{array}$ \\
\hline
\end{tabular}

Note : Final score OWAS varies between 1 to 4 for some elements of work in 1 operation.

Another motion wastes occurred in a handling material activities. Many handling material activities were pursued with a less good posture, for example carrying the load on the shoulders, above his head, and carrying the load below the knee. Carrying the load would be more comfortable in the area of the power zone. The power zone is the lifting region that is considered ergonomically optimal. It extended approximately standing elbow height to standing knuckle height and as close to the body as possible. Figure 2 indicating the activity of non-power zone.
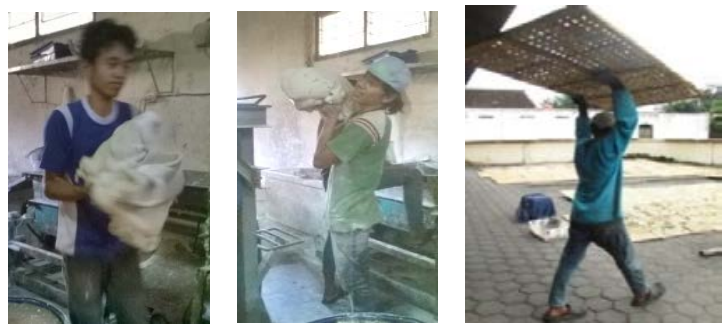

Figure 2. Motion waste : activity of non-power zone

The distance calculation method is aisle distance. In that method, the distance of displacement is calculated from the midpoint of one location to another midpoint location (Fig 3).

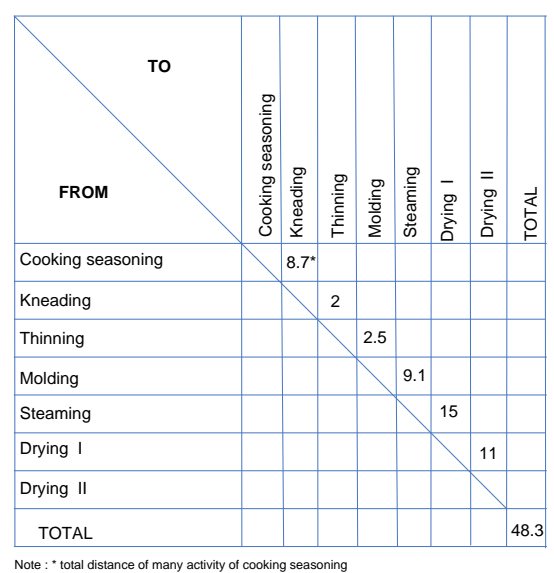

Figure 3. From-to chart : the distance of transportation in meter

Transportation waste occurred in 3 work stations. Setting the layout of two machines molding that placed separately making the distance becomes far by steaming machine. Drying I was pursued in outdoors area of 3 times of total production space area. This causes the distance of displacement of steaming machine be far. From the Drying I to the Drying II approximately $11 \mathrm{~m}$. Transportation waste can be reduced by rearranging the layout of production facilities, moving the unused machine, holding the machine which is a sequence of processes, and putting a machine dryer near the drying I area.

The combination of lean concept and ergonomics approach stated that the worker produce the optimum product with efficient, safe and comfortable as possible while trying to (Walder et al., 2007). Kerts (2011) make a RAPID (Risk and Performance Improvement 
Deployment) method that focus on an easy rules-based approach: find it,fix it and check it for success. Team members walked through the plants, looking for awkward elbow, shoulder and back postures.

Table 2. Elimination waste and improved program

\begin{tabular}{|c|c|c|c|c|c|c|c|}
\hline \multirow[b]{2}{*}{$\begin{array}{c}\text { Opera } \\
\text { tion }\end{array}$} & \multicolumn{3}{|c|}{ Find it } & \multicolumn{4}{|c|}{ Fix it } \\
\hline & $\begin{array}{l}\text { Red } \\
\text { uce } \\
\text { pro } \\
\text { cess }\end{array}$ & $\begin{array}{c}\text { Elimn } \\
\text { ate } \\
\text { motio } \\
\text { n }\end{array}$ & $\begin{array}{c}\text { Reduce } \\
\text { transport } \\
\text { ation }\end{array}$ & $\begin{array}{c}\text { Introd } \\
\text { uce } \\
\text { new } \\
\text { tools }\end{array}$ & $\begin{array}{c}\text { Optimi } \\
\text { zed } \\
\text { layout }\end{array}$ & $\begin{array}{c}\text { New } \\
\text { mach } \\
\text { ine }\end{array}$ & $\begin{array}{c}\text { Soluti } \\
\text { on }\end{array}$ \\
\hline $\begin{array}{l}\text { Cooki } \\
\text { ng } \\
\text { season } \\
\text { ing }\end{array}$ & & $\sqrt{ }$ & & & $\sqrt{ }$ & $\sqrt{ }$ & Mixer \\
\hline $\begin{array}{l}\text { Knead } \\
\text { ing } \\
\text { Thinni } \\
\text { ng }\end{array}$ & & $\sqrt{ }$ & & & $\sqrt{ }$ & & $\begin{array}{l}\text { Vertic } \\
\text { al \& } \\
\text { horizo } \\
\text { ntal } \\
\text { lay out }\end{array}$ \\
\hline $\begin{array}{l}\text { Moldi } \\
\text { ng } \\
\text { Steam } \\
\text { ing }\end{array}$ & & $\checkmark$ & $\sqrt{ }$ & $\checkmark$ & $\sqrt{ }$ & & $\begin{array}{l}\text { Hand } \\
\text { pallet } \\
\text { scissor } \\
\text { s }\end{array}$ \\
\hline $\begin{array}{l}\text { Dryin } \\
\text { g I }\end{array}$ & & $\checkmark$ & $\sqrt{ }$ & $\checkmark$ & $\sqrt{ }$ & & rack \\
\hline $\begin{array}{l}\text { Dryin } \\
\text { g II }\end{array}$ & $\sqrt{ }$ & & & & & & \\
\hline
\end{tabular}

RAPID increase productivity and improve associate safety at the same time. Lean / ergo recognizes the need for equipment design to make work easier for the operator. Four specific issues are targeted by RAPID

- working posture

- handling weight and part as of tools

- assembling muscle power (pushing, pulling or putting-in movement)

- sustaining time at operator

In line with the RAPID method that aims to improve ergonomics workers in this study were obtained the following results

Waste motion occurs in all processes. Workers work with awkward posture due to the limited area and un-ergonomic machine. The use of mixer can eliminate waste motion in the cooking seasoning. Excessive repetition on the molding, steaming and drying can't be reduced but the high force material handling can be minimalized with the hand pallet scissors. Redesign the layout of horizontal and vertical can reduce waste motion waste, and transportation waste at all stages.

\section{CONCLUSION}

Implementation of lean ergonomic in crackers industry shows that motion waste becomes the most important thing that should be immediately solved with improvements the vertical and horizontal layout.

\section{SUGGESTION}

Two ergo waste by Woolley \& Armstrong (2012) were fatigue waste and musculoskeletal disorders waste join examined.

\section{REFERENCE}

Walder, Jon., J. Karlin and C. Kerk, Integrated Lean Thinking \& Ergonomics : Utilizing Material Handling Assist Device Solutions for a Productive Workplace, South Dakota School of Mines, www.MHIA.org, 2007

Kerts, Josh., Lean Ergonomics - RAPID Improvements within Hands-on Engagement, www.timken.com, 2011. diakses tanggal 20 September 2015 pukul 05.35

Woolley, C.B. and Armstrong, T.J., Lean Production and Ergonomics : Friend or Foe ?, Univesity of Michigan Center for Ergonomics, personal.umich.edu/tja/, 2012

Lee., Quarterman and W Nelson, Ergonomics in Lean Manufacturing, www.strategosinc.com, Kansas City, USA

Handayani, E.M., 2014, Implementasi Lean Manufacturing dengan Pendekatan Value Stream Mapping untuk Mereduksi Resiko Pemborosan di Industri Kerupuk Subur Yogyakarta, Skripsi FTP UGM Yogyakarta

Baasithu, A., 2015, Penentuan Tingkat Beban Kerja Fisik dan Waktu Istirahat Berasarkan Kriteria Fisiologis Pekerja di Industri Kerupuk Subur Yogyakarta, Skripsi FTP UGM Yogyakarta. 